\title{
Chromium (VI) Ion Adsorption Features of Chitosan Film and Its Chitosan/Zeolite Conjugate 13X Film
}

\author{
Anabelle C. L. Batista ${ }^{1,2}$, Emílio R. Villanueva ${ }^{3}$, Rosa Valéria S. Amorim ${ }^{4}$, \\ Maria Teresa Tavares ${ }^{5}$ and Galba M. Campos-Takaki ${ }^{2, *}$
}

1 Rede Nordeste de Biotecnologia (RENORBIO), Universidade Estadual do Ceará, Av. Paranjana, 1.700, Campus do Itaperi, 60740-000 Fortaleza, CE, Brazil; E-Mail: ellecamarotti@yahoo.com.br

2 Núcleo de Pesquisas em Ciências Ambientais (NPCIAMB), Universidade Católica de Pernambuco, Boa Vista 50 050-590 Recife, PE, Brazil

3 Departamento de Engenharia Química, Universidade de Vigo, Spain; E-Mail: emiliorv@uvigo.es

4 Departamento de Histologia e Morfologia, Universidade Federal de Pernambuco, Av. Prof. Moraes Rego, 1235, Cidade Universitária, 50670-901, Recife, PE, Brazil; E-Mail: rosa.amorim@ufpe.br

5 Instituto de Biotecnologia e Bioengenharia (IBB), Universidade do Minho, Campus de Gualtar, 4710-057 Braga, Portugal; E-Mail: ttavares@deb.uminho.pt

* Author to whom correspondence should be addressed; E-Mail: galba_takaki@yahoo.com.br; Tel.: +55 8121194017 ; Fax: +55 8121194043 .

Received: 20 January 2011; in revised form: 21 February 2011 / Accepted: 9 March 2011 / Published: 28 April 2011

\begin{abstract}
This research evaluated the importance of the adsorption properties of chitosan a chitosan/zeolite conjugate film for the removal of $\mathrm{Cr}(\mathrm{VI})$ ions from solutions in the $5-260 \mathrm{mg} / \mathrm{L}$ concentration range, when the $\mathrm{pH}$ was adjusted to 4.0 and 6.0. The uptake capacities of the films formed by chitosan and by the chitosan/zeolite conjugate were calculated by mass balance. The equilibrium isotherms were fitted to the Langmuir, Freundlich and Redlich-Peterson models. The chitosan film seems to be a good sorbent for $\mathrm{Cr}(\mathrm{VI})$ at $\mathrm{pH} 4$, but its physical instability suggests the need for a more resilient support. Due to this fact zeolite was added to the chitosan matrix in solution and a chitosan/zeolite (CS/Zeo) film was thus formed. The solubility of the film and the characterization of the different matrices by FTIR, TGA and X-Ray showed that a cross-linked structure was formed between the chitosan and zeolite and the solubility of the film increased. In this study, the low manufacturing cost of the CS/Zeo matrix, the good uptake of Cr(VI) at
\end{abstract}


acidic $\mathrm{pH}(17.28 \mathrm{mg} / \mathrm{g})$ and the non desorption of $\mathrm{Cr}(\mathrm{VI})$ from the film in water suggests this combination should be tested in industrial environment.

Keywords: chitosan; zeolite; chromium; adsorption

\section{Introduction}

Chitin $(\mathrm{CH})$ has been widely used for cosmetics, feed additives and so on due to the fact it is a harmless and inexpensive material, and the good adsorption performance of chitin has been shown. Nowadays, several technologies using microorganisms, chitosan (CS) or zeolites (Zeo) have been tested as ways of removing heavy metals from the environment [1-6]. During the adsorption process by CS, the nitrogen from the amino group of CS acts as an electron donor is thought to be mainly responsible for the adsorption of metal ions, although metals can also bind with the free hydroxyl groups in the CS molecule [7]. Zeolite is a naturally occurring mineral group consisting of over 50 different minerals. The $13 \mathrm{X}$ zeolite was chosen to crosslink with CS because it shows excellent stability in acid solutions, supports high temperatures and it has been already tested as a non $\operatorname{Cr}(\mathrm{VI})$ adsorbent [8]. This combination of substances (CS/Zeo) to form a film has been successfully used in pervaporation experiments with organic-water systems [9-11].

In this study, the heavy metal adsorption efficiency of CS was combined with the excellent physicochemical properties of the zeolite to improve film performance. The chemical changes resulting from these combinations were investigated and the adsorption/desorption experiments were evaluated using $\mathrm{Cr}(\mathrm{VI})$, a metal commonly found in industrial wastewaters. The adsorption isotherms of $\mathrm{Cr}(\mathrm{VI})$ ions on CS and CS cross linked with Zeo films were studied for purposes of comparison.

\section{Results and Discussion}

\subsection{Film characterization}

The preliminary results obtained with CS film (Table 1) showed that its solubility in water increases when the chitosan concentration on the film increases. This is justified by the high hydrophilicity of chitosan, which is dependent on the presence of $-\mathrm{NH}_{2}$ and $-\mathrm{OH}$ groups. The increased amount of intermolecular bonds between free reactive groups of internal residues of chitosan is also suggested as a facilitator of increased resistance to solubilization and the resistance to degradation of the film $[12,13]$. The CS/Zeo films demonstrated good physical stability in metal solutions, being more soluble at $\mathrm{pH} 4.0$ than $\mathrm{pH} 6.0$, depending on the metal concentration in solution (Table 1). The decreased solubility of CS $0.5 \%$ and CS/Zeo films in solutions ranging from $5 \mathrm{mg} / \mathrm{L}$ to $260 \mathrm{mg} / \mathrm{L}$ of $\mathrm{Cr}(\mathrm{VI})$ concentration at $\mathrm{pH} 4.0$ occurred presumably due to the formation of a large amount of electrostatic bonds between the reactive $\mathrm{NH}_{2}$ group of $\mathrm{CS}$ and the major $\mathrm{HCrO}_{4}{ }^{-}$form of $\mathrm{Cr}(\mathrm{VI})$ at low $\mathrm{pH}$, which increased the resistance to solubility. The increased solubility of the films in solutions from $5 \mathrm{mg} / \mathrm{L}$ to $260 \mathrm{mg} / \mathrm{L}$ of $\mathrm{Cr}(\mathrm{VI})$ concentration at $\mathrm{pH} 6.0$ is potentially due to the lesser formation of electrostatic bonds between the reactive groups of the CS and $\mathrm{Cr}(\mathrm{VI})$, that favors the instability of the films [10-12]. Films with solubility higher than $35 \%$ in water and $\operatorname{Cr}(\mathrm{VI})$ solution demonstrated 
instability of their integrity during the assays. Enhanced resistance of chitosan to acids and chemicals was suggested previously $[11,14,15]$.

Table 1. Effect of chitosan concentration, presence and metal concentration and $\mathrm{pH}$ onto the chitosan (CS) and chitosan/zeolite (CS/Zeo 1:10 w/w) film solubility.

\begin{tabular}{cccccc}
\hline Film (w/v) & Solution & Solubility & Film (w/v) & Solution & Solubility \\
\hline $\mathrm{CS} 0.5 \%$ & $\mathrm{H}_{2} \mathrm{O}$ pH 4.0 & $27.71 \%$ & $\mathrm{CS} 0.5 \%$ & $\mathrm{Cr}(\mathrm{VI}) 5 \mathrm{mg} / \mathrm{L} \mathrm{pH} 4.0$ & $23.40 \%$ \\
$\mathrm{CS} 1.5 \%$ & $\mathrm{H}_{2} \mathrm{O}$ pH 4.0 & $30.82 \%$ & $\mathrm{CS} 0.5 \%$ & $\mathrm{Cr}(\mathrm{VI}) 260 \mathrm{mg} / \mathrm{L} \mathrm{pH} 4.0$ & $2.60 \%$ \\
$\mathrm{CS} 2.5 \%$ & $\mathrm{H}_{2} \mathrm{O}$ pH 4.0 & $33.31 \%$ & $\mathrm{CS} / \mathrm{Zeo}$ & $\mathrm{Cr}(\mathrm{VI}) 5 \mathrm{mg} / \mathrm{L} \mathrm{pH} 4.0$ & $35.96 \%$ \\
$\mathrm{CS} 0.5 \%$ & $\mathrm{H}_{2} \mathrm{O}$ pH 6.0 & $18.70 \%$ & $\mathrm{CS} / \mathrm{Zeo}$ & $\mathrm{Cr}(\mathrm{VI}) 260 \mathrm{mg} / \mathrm{L} \mathrm{pH} 4.0$ & $25.54 \%$ \\
$\mathrm{CS} 1.5 \%$ & $\mathrm{H}_{2} \mathrm{O}$ pH 6.0 & $25.93 \%$ & $\mathrm{CS} 0.5 \%$ & $\mathrm{Cr}(\mathrm{VI}) 5 \mathrm{mg} / \mathrm{L} \mathrm{pH} 6.0$ & $12.31 \%$ \\
$\mathrm{CS} 2.5 \%$ & $\mathrm{H}_{2} \mathrm{O}$ pH 6.0 & $29.29 \%$ & $\mathrm{CS} 0.5 \%$ & $\mathrm{Cr}(\mathrm{VI}) 260 \mathrm{mg} / \mathrm{L} \mathrm{pH} 6.0$ & $30.51 \%$ \\
$\mathrm{CS} / \mathrm{Zeo}$ & $\mathrm{H}_{2} \mathrm{O}$ pH 4.0 & $18.80 \%$ & $\mathrm{CS} / \mathrm{Zeo}$ & $\mathrm{Cr}(\mathrm{VI}) 5 \mathrm{mg} / \mathrm{L} \mathrm{pH} 6.0$ & $35.81 \%$ \\
$\mathrm{CS} / \mathrm{Zeo}$ & $\mathrm{H}_{2} \mathrm{O}$ pH 6.0 & $16.40 \%$ & $\mathrm{CS} / \mathrm{Zeo}$ & $\mathrm{Cr}(\mathrm{VI}) 260 \mathrm{mg} / \mathrm{L} \mathrm{pH} 6.0$ & $40.92 \%$ \\
\hline
\end{tabular}

In Figure 1 is possible to observe in chitosan film the bands of amine $\mathrm{I}\left(\sim 1,650 \mathrm{~cm}^{-1}\right)$, amine II $\left(\sim 1,590 \mathrm{~cm}^{-1}\right)$ and C-O stretching vibrations $\left(\sim 1,200-1,000 \mathrm{~cm}^{-1}\right)$, all characteristic of CS (Figure 1A) and the bands of Si-O and C-O stretching vibration $\left(\sim 1,200-1,000 \mathrm{~cm}^{-1}\right)$ characteristics of Zeo on zeolite powder (Figure 1B). The $\mathrm{O}-\mathrm{H}$ stretching vibration $\left(\sim 3,440 \mathrm{~cm}^{-1}\right)$ appeared in all samples tested with different intensities according to the concentrations of reactive $\mathrm{OH}$ - present in the molecules. The decreased of the intensity of the characteristic peaks of CS film and Zeo powder on the CS/Zeo film is suggested by the formation of intermolecular cross-links between CS and Zeo during the formation of the film. This decrease was observed previously by Wang et al. [11] in different kinds of zeolite and by Kittur et al. [16], who described that this decrease is dependent on the zeolite content in the membrane. The weakening of C-O stretching vibration to $\mathrm{CS} /$ Zeo film when compared with CS film is suggested as the result of hydrogen bonds between chitosan and zeolite [11]. The absence of transmittance difference between the $\mathrm{C}-\mathrm{O}$ stretching vibration on $\mathrm{CS} /$ Zeo film and Zeo powder suggest the incorporation of zeolite crystals in the matrice of chitosan film, which is confirmed by X-ray analysis. Intermolecular hydrogen bonds between CS and other compounds to form films were reported earlier to favor the formation of pores in the structure [17].

The X-ray diffraction studies confirmed the semi-crystallinity of CS and the crystallinity of zeolite. In this study, the CS film shows mainly the form I, where the amine groups may be involved in the stability of the semi-crystalline molecule and in the control of the accessibility to adsorption sites, as confirmed by the peak at $11.2^{\circ}$ present in CS film $0.5 \%(\mathrm{w} / \mathrm{v})$ (Figure 2). The introduction of Zeo particles into CS matrices increased the crystallinity of the film and the thermal stability, although it decreases the flexibility. The CS/Zeo film showed some characteristic peaks of both components and the differences may be justified by the incorporation of zeolite crystals in the chitosan film matrices, which may affect the adsorption process of the metal by the CS/Zeo film, as confirmed by adsorption experiments [10,11,14,16]. 
Figure 1. FTIR spectra of chitosan film (A), zeolite powder (B) and chitosan/zeolite film $(1: 10 \mathrm{w} / \mathrm{w})(\mathbf{C})$.
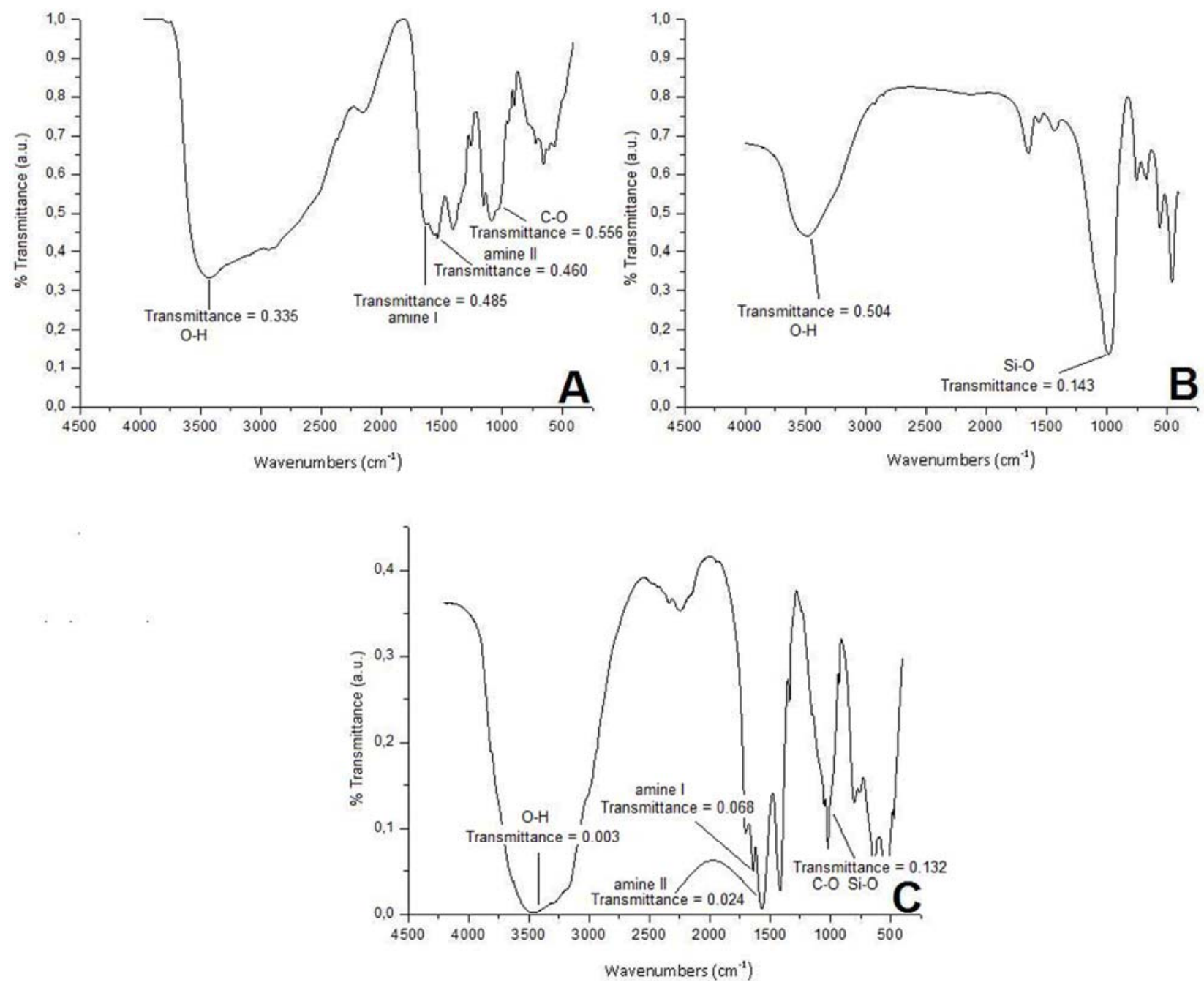

Figure 2. X-ray patterns of chitosan film $0.5 \%$, chitosan/zeolite film $(1: 10 \mathrm{w} / \mathrm{w})$, zeolite $13 \mathrm{X}$ and chitosan powder.
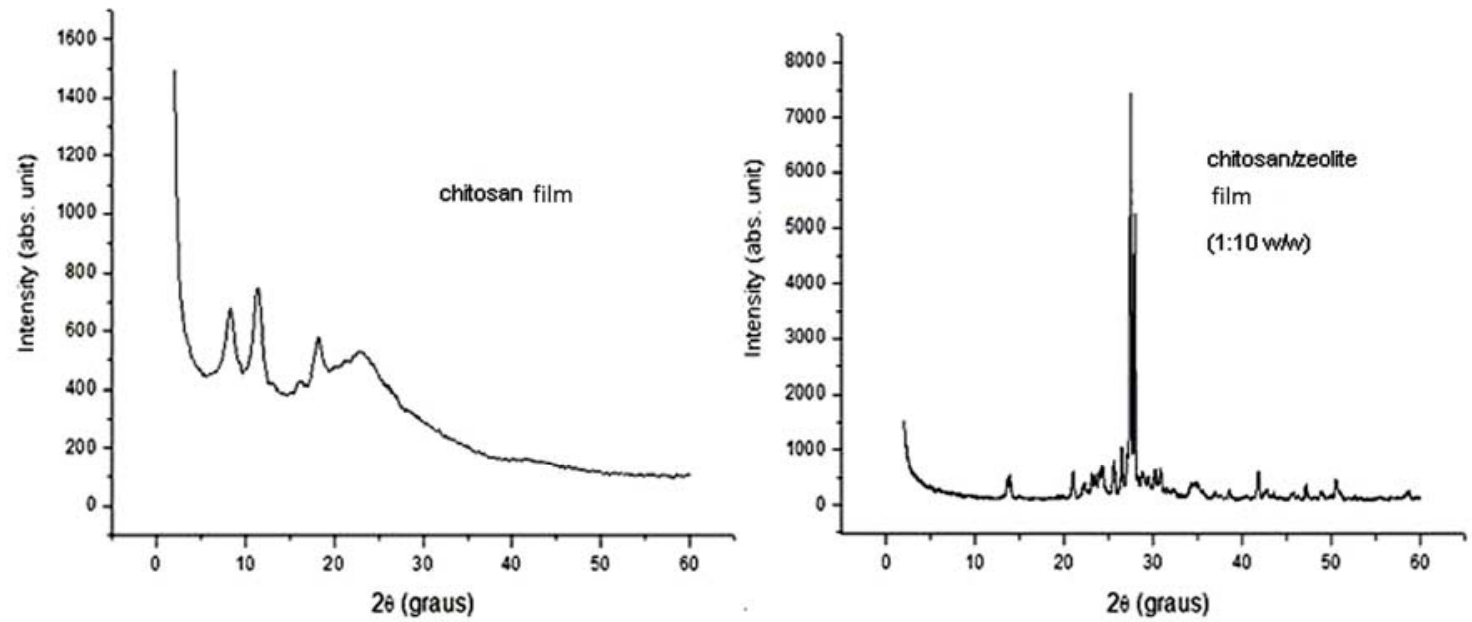
Figure 2. Cont.
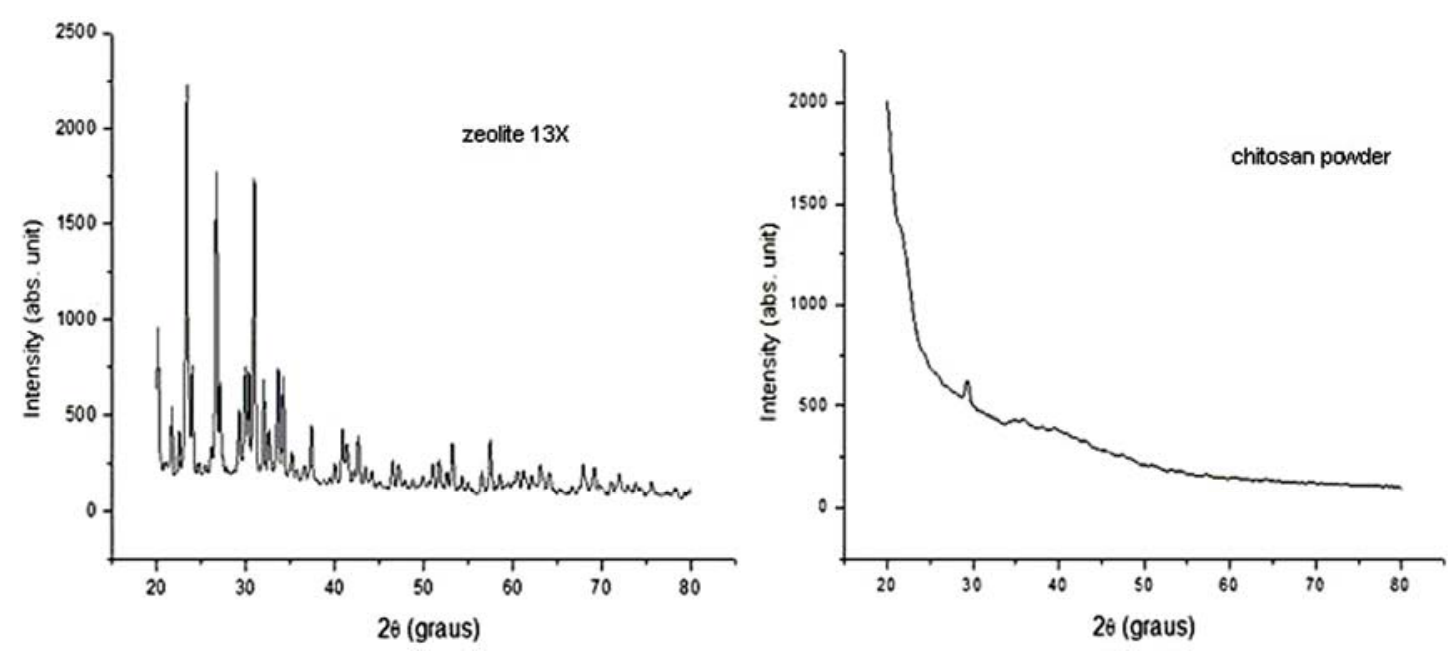

The TGA curves show two endothermic peaks for the CS film and only one endothermic peak for the Zeo powder, as shown in Figure 3. The first peak corresponds to loss of water in all substances tested and the second peak corresponds to the degradation of the sample. This excessive loss of water of CS film in the range of $100-110^{\circ} \mathrm{C}$ may limit its applications in different water systems. The higher thermal stability of the $\mathrm{CS} /$ Zeo film, evidenced by a gentle peak in the $110-350{ }^{\circ} \mathrm{C}$ region, suggests a low decomposition of the main chain of CS and a strong interaction between the CS and the Zeo used in these studies, as shown in Figure 3 [11,13,18,19].

Figure 3. TGA results of pure zeolite powder (A), chitosan/zeolite film (B) and chitosan film (C).

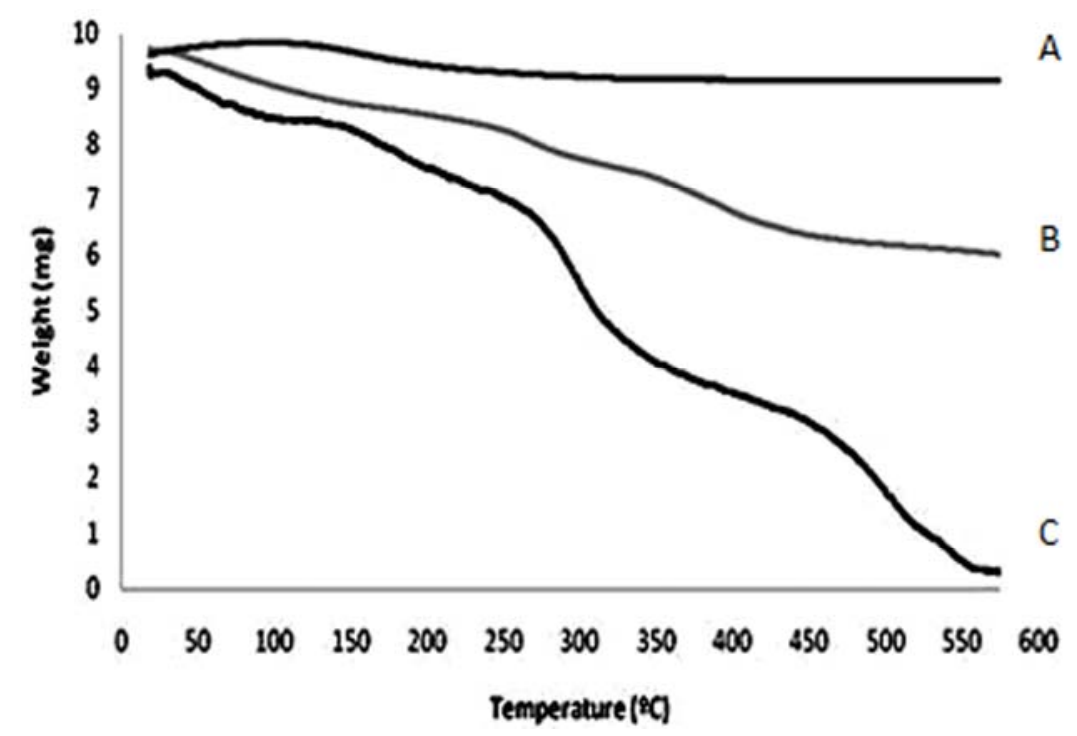

\subsection{Adsorption/desorption Experiments}

The first stage of experiments aimed to analyze the adsorption of $\mathrm{Cr}(\mathrm{VI})$ at $\mathrm{pH} 6.0$ by $\mathrm{CS}$ films prepared in three different concentrations $(0.5-2.5 \% \mathrm{w} / \mathrm{v})$, to select the best formulation for the association of chitosan with zeolite. The first experiments showed the physical stability of the CS film at $2.5 \%(\mathrm{w} / \mathrm{v})$ in all solutions of $\mathrm{Cr}(\mathrm{VI})$. However, higher removal efficiency has been observed when 
$0.5 \%$ CS film was used. In order to maximize the efficiency of metal removal in solution using a batch systems and to reduce the cost of the adsorption operation we selected $0.5 \%(\mathrm{w} / \mathrm{v}) \mathrm{CS}$ film to continue the experiments and for cross linking with the Zeo to form CS/Zeo 1:10 (w/w) films. The adsorption experiments with Zeo pellets demonstrated the non adsorption of $\mathrm{Cr}(\mathrm{VI})$ at different $\mathrm{pHs}$ or metal concentrations. The literature confirmed that there no adsorption of $\mathrm{Cr}(\mathrm{VI})$ by zeolite with unaltered surfaces, although the tailoring of zeolite surface is possible and could enable the adsorption of $\mathrm{Cr}(\mathrm{VI})[3,20]$.

At $\mathrm{pH} 4.0$ the adsorption capacity of CS film was not favored because under these $\mathrm{pH}$ conditions, the CS film was completely dissolved in the first thirty minutes of the experiment at concentrations of $\mathrm{Cr}(\mathrm{VI})$ lower than $130 \mathrm{mg} / \mathrm{L}$. The incorporation of Zeo in the inner structure of the chitosan matrix, as confirmed by FTIR and X-ray, stabilized the film at concentrations that ranged from $5-260 \mathrm{mg} / \mathrm{L}$ at the initial $\mathrm{pH}$ values of 4.0 and 6.0. This effort to stabilize the CS film through association with other substances for use in metal adsorption was also described by other authors [10,14,15,18,19,21]. Baroni et al. [18] argued that quantitative analyses of $\mathrm{Cr}(\mathrm{VI})$ may present errors that are significant in batch experiments with concentrations lower than $250 \mathrm{mg} / \mathrm{L}$ using cross-linked films of chitosan. However, the CS/Zeo films used in this research study were able to stabilize the adsorption kinetics in concentrations of $\mathrm{Cr}(\mathrm{VI})$ from $130 \mathrm{mg} / \mathrm{L}$ with an adsorption uptake of $17.28 \mathrm{mg} / \mathrm{g}$ at $\mathrm{pH} 4.0$ and $8.78 \mathrm{mg} / \mathrm{g}$ at $\mathrm{pH} 6.0$ until equilibrium in $12 \mathrm{~h}$ (Figure 4). The influence of $\mathrm{pH}$ on $\mathrm{Cr}(\mathrm{VI})$ adsorption was described previously suggesting that the protonated form of chitosan at $\mathrm{pH} 4.0$ can facilitate the chelation or electrostatic interaction with $\mathrm{Cr}(\mathrm{VI})$ in solution $[18,19]$.

Figure 4. Adsorption kinetic curves for $\mathrm{Cr}(\mathrm{VI})$ on chitosan/zeolite film (full line) and evaluation of $\mathrm{pH}$ during assays (dotted line).

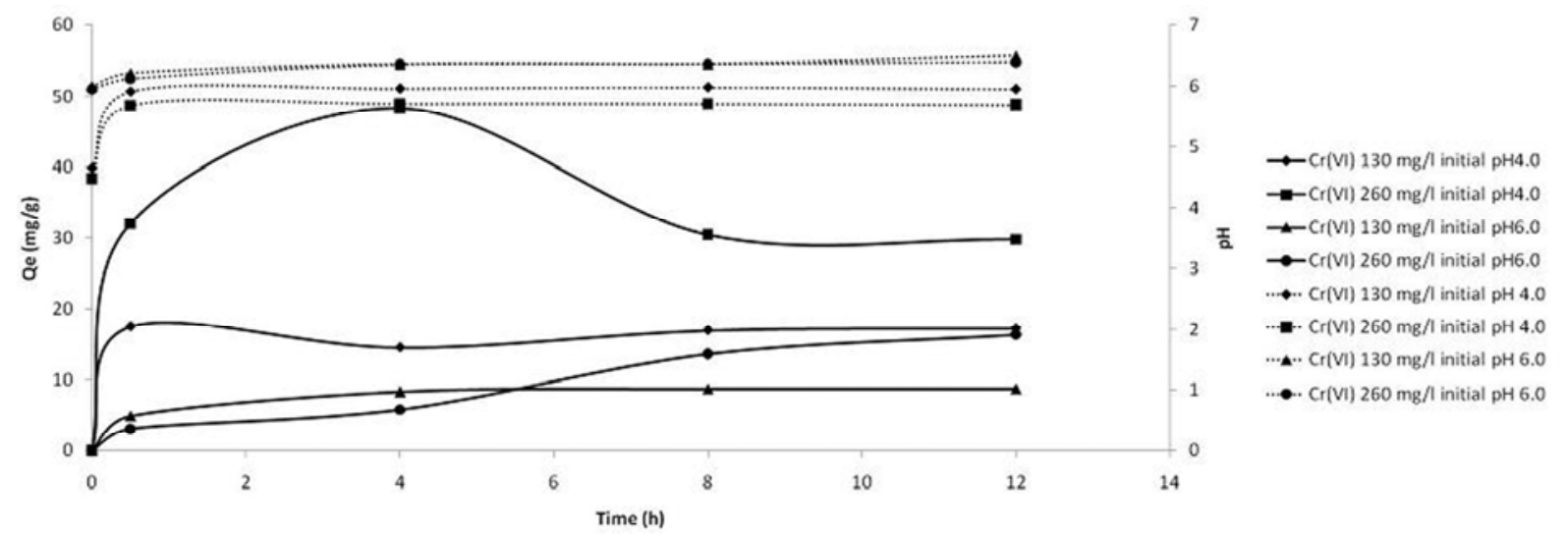

In Figure 4, it is observed that the adsorption equilibrium is rapidly reached and that it is related to the increase in $\mathrm{pH}$ from 4.0 to $\sim 6.5$ during the assays, which may have interfered with the protonation of the chitosan $\mathrm{NH}_{2}$ sites. The increase in $\mathrm{pH}$ is suggested by the release of $\mathrm{Na}+$ from $\mathrm{CS} /$ Zeo film into the solution. At $\mathrm{pH} 4.0$ the majority of the $\mathrm{CS}$ presents the protonated form $\mathrm{NH}_{3}{ }^{+}$which favors the formation of electrostatic bonds in a larger amount than in systems where the $\mathrm{pH}$ is closer to a neutral value [22,23]. This increase of electrostatic bonds with a large amount of $\mathrm{Cr}(\mathrm{VI})$ decreased the solubility at acid pHs. At pH 6.0 the CS presents both reactive forms $-\mathrm{NH}_{3}{ }^{+} /-\mathrm{NH}_{2}$ and $\mathrm{Cr}$ (VI) the forms $\mathrm{HCrO}_{4}{ }^{-}(\sim 75 \%)$ and $\mathrm{CrO}_{4}{ }^{2-}(\sim 25 \%)$ at $25^{\circ} \mathrm{C}$, suggesting that the phenomenon of adsorption of 
$\mathrm{Cr}(\mathrm{VI})$ by CS/Zeo film occurred by chelation and electrostatic interaction with the amine groups of CS and the reactive forms of $\mathrm{Cr}(\mathrm{VI})[14,18]$. The diminished adsorption of $\mathrm{Cr}(\mathrm{VI})$ by $\mathrm{CS} / \mathrm{Zeo}$ film at $\mathrm{pH}$ 6.0 than $\mathrm{pH} 4.0$ is suggest to be due to a reduction of protonated reactive forms in CS. The release of $\mathrm{Cr}(\mathrm{VI})$ to the solution between $4-8 \mathrm{~h}$ at $\mathrm{pH} 4.0$ by CS/Zeo film is suggested by the solubility of a part of the film during the assay (photographic data not shown), however the contact time up to $12 \mathrm{~h}$ favored the chelation of the majority of $\mathrm{Cr}(\mathrm{VI})$ from the solution when compared with $\mathrm{pH} 6.0$ under the same $\mathrm{Cr}(\mathrm{VI})$ concentration conditions. During the desorption experiments there was no desorption of $\mathrm{Cr}(\mathrm{VI})$ in distilled water, which confirmed the strong interaction of $\mathrm{CS} / \mathrm{Zeo}$ film and the $\mathrm{Cr}(\mathrm{VI})$.

\subsection{Adsorption isotherms}

Equilibrium isotherms are used to upscale laboratorial batch experiments to a pilot or industrial scale. The equilibrium data of metallic ions adsorption by $\mathrm{CS} /$ Zeo film was modeled to the following linearized forms: $\mathrm{Ce} / \mathrm{Qe}=1 / \mathrm{amb}+(1 / \mathrm{am}) \mathrm{Ce}($ Langmuir linear equation); $\operatorname{logQe}=\log \mathrm{Kf}+(1 / \mathrm{n})$ $\log \mathrm{Ce}($ Freundlich linear equation); $\ln (\mathrm{KR}(\mathrm{Ce} / \mathrm{Qe})-1)=\mathrm{aR} \ln (\mathrm{Ce})+\ln (\beta)$ (Redlich-Peterson linear equation) (Table 2).

Table 2. Adsorption constants and fitting regression parameters for the isotherm models studied for $\mathrm{Cr}$ (VI) onto chitosan/zeolite film, at $\mathrm{pH} 4.0$ and 6.0.

\begin{tabular}{c|c}
\hline Variables & $\begin{array}{c}\text { Equilibrium Isotherms } \\
\text { Models }\end{array}$ \\
\hline $\mathrm{Q}_{\max }=66.8000, \mathrm{~b}=0.0030, \mathrm{R}^{2}=0.9940(\mathrm{pH} \mathrm{4.0)}$ \\
$\mathrm{Q}_{\max }=21.0370, \mathrm{~b}=0.0081, \mathrm{R}^{2}=0.9830(\mathrm{pH} 6.0)$ & Langmuir \\
\hline $\mathrm{K}_{\mathrm{f}}=0.3679, \mathrm{n}=1.2548, \mathrm{R}^{2}=0.9893(\mathrm{pH} 4.0)$ & Freudlich \\
$\mathrm{k}_{\mathrm{f}}=0.6949, \mathrm{n}=1.8027, \mathrm{R}^{2}=0.9977(\mathrm{pH} \mathrm{6.0)}$ & Redlich-Peterson \\
\hline $\mathrm{K}_{\mathrm{r}}=0.2004, \mathrm{a}_{\mathrm{R}}=0.0030, \beta=1.0000, \mathrm{R}^{2}=0.9940(\mathrm{pH} 4.0)$ & \\
\hline
\end{tabular}

All models tested showed a good $\mathrm{R}$ parameter $(\sim 0.98-0.99)$ depending on initial $\mathrm{pH}$. At initial $\mathrm{pH}$ 4.0 both Langmuir and Redlich-Peterson models showed the best fit; at $\mathrm{pH}$ 6.0, the Freundlich model showed a better fit. The assay at $\mathrm{pH} 6.0$ did not allow the fitting of the Redlich-Peterson model as shown in Figure 5. These results indicate that adsorption at $\mathrm{pH} 4.0$ occurred, preferably, by means of formation of a monolayer on the film surface. This linkage at $\mathrm{pH} 4.0$ is supposed to happen by electrostatic interaction and occurred for a high concentration of $\mathrm{Cr}(\mathrm{VI})$ in solution. At $\mathrm{pH} 6.0$ and in a low concentration range of $\mathrm{Cr}(\mathrm{VI})$, it is suggested that the adsorption occurs by chelation on energetically heterogeneous active sites present on the film surface, as shown in Figure 5 [5,18,19,24]. 
Figure 5. Comparison between experimental data of $\mathrm{Cr}(\mathrm{VI})$ adsorption on chitosan/zeolite film and those predicted by the three models tested, at two $\mathrm{pH}$ sets.
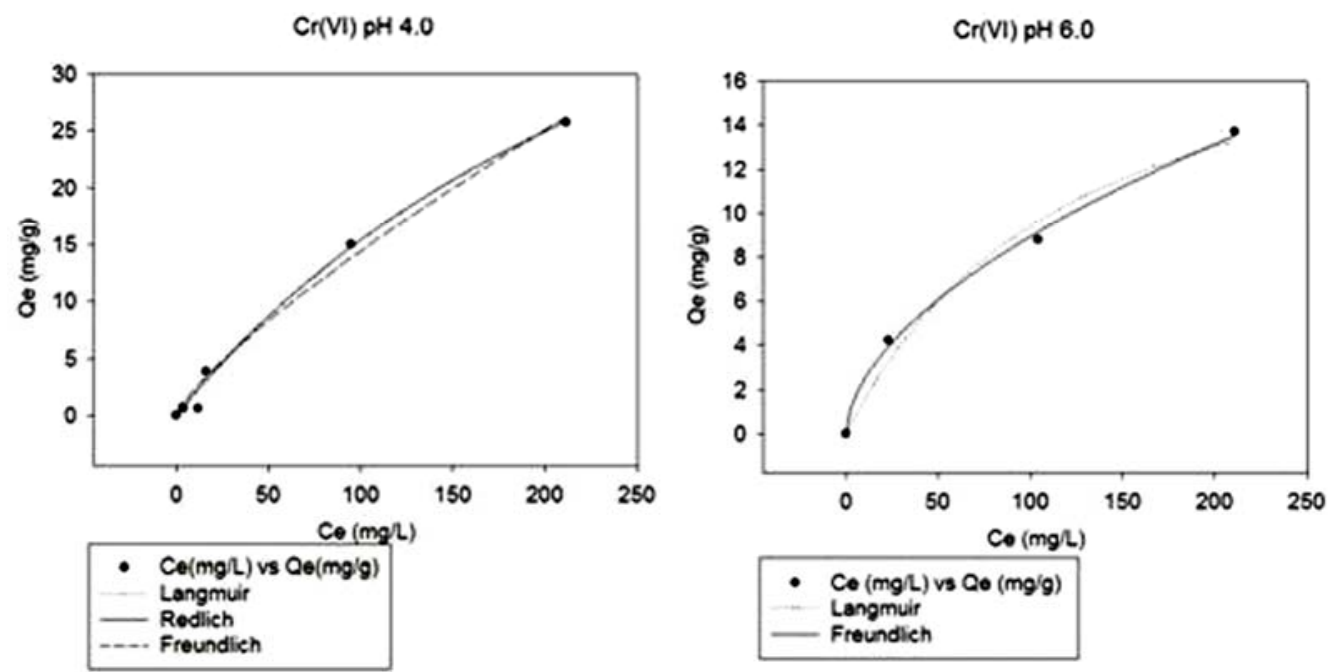

\section{Experimental}

\subsection{Materials}

Chitosan (degree of deacetylation (DD) 90\%) was purchased from Aqua Premier Company, Thailand. Zeolite 13X (hydrophilic; particle diameter $=5-8 \mathrm{~mm}$; pore diameter $=13 \AA$ ) was purchased from Xiamen Zhongzhao Imp. \& Exp. The zeolite was calcined at $500{ }^{\circ} \mathrm{C}$ during $8 \mathrm{~h}$ under a dry air stream prior to use. Acetic acid (99\%) was purchased from Sigma-Aldirich (St Louis, MO, USA) and diluted to $1 \%(\mathrm{v} / \mathrm{v})$ in distilled water. The standard metal solution was prepared starting with $2.828 \mathrm{~g} / \mathrm{L}$ of $\mathrm{K}_{2} \mathrm{Cr}_{2} \mathrm{O}_{7}$ (Panreac) and $\mathrm{pH}$ was adjusted to 4.0 and $6.0\left(0.1 \mathrm{~mol} / \mathrm{L} \mathrm{H}_{2} \mathrm{SO}_{4} ; 0.1 \mathrm{~mol} / \mathrm{L} \mathrm{NaOH}\right)$.

\subsection{Film Preparation and Characterization}

Solutions of crustacean CS were prepared in acetic acid $(1 \% \mathrm{v} / \mathrm{v})$ and ranged from $0.5-2.5 \mathrm{wt} \%$. CS and CS/Zeo $(1: 10 \mathrm{w} / \mathrm{w})$ films were prepared as per Liu et al. [10]. The percentage of zeolite in chitosan film was selected based on optimal performance in the pervaporation and direct methanol fuel cell (DMFC) process [10,11]. All films were kept in an dessicator for a minimum of $24 \mathrm{~h}$ before use.

The films were characterized in terms of water solubility and in terms of structure by X-ray diffractometry, thermogravimetric analysis (TGA - Shimadzu, model TGA-50)) and by Fourier Transmittance Infra-Red spectroscopy (FTIR) obtained from powdered samples on $\mathrm{KBr}$ pellets, using a Bomem MB104 spectrometer in the range $(4,000-500) \mathrm{cm}^{-1}$ by averaging 20 scans at a maximum resolution of $10 \mathrm{~cm}^{-1}[12,13,16]$.

\subsection{Adsorption/Desorption experiments}

The adsorption assays were performed with the addition of only one film per batch $( \pm 50 \mathrm{mg} \mathrm{CS}$; $\pm 298 \mathrm{mg} \mathrm{CS} /$ Zeo per film). Control assay was performed with distillated water and pellets of zeolite $1 \mathrm{wt} \%$. The glass bottles with $500 \mathrm{~mL}$ of metal solution in different concentration $(5-260 \mathrm{mg} / \mathrm{L})$ and with the adsorbent were kept at $25{ }^{\circ} \mathrm{C}, 150 \mathrm{rpm}$ per $12 \mathrm{~h}$ and small aliquots were withdrawn. Total 
concentrations of the metal were measured by Atomic Absortion (AAS), using a Varian Spectra AA-400. After analysis, the solutions were treated according to Standard Methods [25]. The adsorption uptake was calculated by mass balance. The equilibrium isotherms were fitted to the Langmuir, Freundlich and Redlich-Peterson models. During the batch experiments, the $\mathrm{pH}$ of the solutions was not controlled, because the literature reported that the addition of $\mathrm{HCl}$ or $\mathrm{NaOH}$ to control $\mathrm{pH}$ would change the adsorption conditions [26]. Desorption studies were performed per Baroni et al. [18], with some modifications. The chitosan film was immersed in $100 \mathrm{~mL}$ of distilled water for $24 \mathrm{~h}$ with stirring at $200 \mathrm{rpm}$. The metal concentration in solution was measured as previously described.

\section{Conclusions}

This study establishes the ability of CS/Zeo film to adsorb low concentrations of hexavalent chromium from aqueous solutions. The low cost of the matrix manufacture, the good uptake of $\mathrm{Cr}(\mathrm{VI})$ at acid $\mathrm{pH}(17.28 \mathrm{mg} / \mathrm{g})$ and the non desorption of $\mathrm{Cr}(\mathrm{VI})$ from the film in water suggests that this combination of chitosan and zeolite could be tested in industrial environments. The industrial approach of this film is suggested to meet the requirements of the current environmental legislation.

\section{Acknowledgements}

The authors are grateful for the Coordination of Improvement of Higher Education Personnel (CAPES - Brazil) for PhD fellowship and the financial support received from Financier of Studies and Projects (FINEP - Brazil), National Council for Scientific and Technological Development (CNPq Brazil), Catholic University of Pernambuco (UNICAP - Brazil), University of Minho (UMINHO Portugal). They also acknowledge António Soares Vicente (UMINHO - Portugal) who kindly supplied the chitosan.

\section{References}

1. Don, T.-M.; King, C.-F.; Chiu, W.-Y. Preparation of chitosan-graft-poly(vinyl acetate) copolymers and their adsorption of copper ion. Polym. J. 2002, 34, 418-425.

2. Ahmaruzzaman, M.D. Adsorption of phenolic compounds on low-cost adsorbents: A review. Adv. Colloid Interface Sci. 2008, 143, 48-67.

3. Silva, B.; Figueiredo, B.; Quintelas, C.; Neves, I.C.; Tavares, T. Zeolites as supports for the biorecovery of hexavalent and trivalent chromium. Micropor. Mesopor. Mat. 2008, 116, 555-560.

4. Quintelas, C.; Fonseca, B.; Silva, B.; Figueiredo, H.; Tavares, T. Treatment of chromium(VI) solutions in a pilot-scale bioreactor through a biofilm of Arthrobacter viscosus supported on GAC. Bioresource Technol. 2009, 100, 220-226.

5. Kyzas, G.Z.; Kostoglou, M.; Lazaridis, N.K. Copper and chromium(VI) removal by chitosan derivatives_Equilibrium and kinetic studies. Chem. Eng. J. 2009, 152, 440-448.

6. Abdel-Razek, A.S.; Abdel-Ghany, T.M.; Mahmoud, S.A.; El-Sheikh, H.H.; Mahmoud, M.S. The use of free and immobilized Cunninghamella elegans for removing cobalt ions from aqueous waste solutions. World J. Microb. Biot. 2010, 25, 2137-2145. 
7. Pradhan, S.; Shukla, S.S.; Dorris, K.L. Removal of nickel from aqueous solutions using crab shells. J. Hazard. Mater. 2005, 25, 201-204.

8. Erdem, E.; Karapinar, N.; Donat, R. The removal of heavy metal cations by natural zeolites. J. Colloid Interface Sci. 2004, 280, 309-314.

9. Qiao, X.; Chung, T.-S.; Rajagopalan, R. Zeolite filled P84 co-polyimide membranes for dehydration of isopropanol through pervaporation process. Chem. Eng. J. 2006, 61, 6816-6825.

10. Liu, B.; Cao, Y.; Wang, T.; Yuan, Q. Preparation of novel ZSM-5 zeolite-filled chitosan membranes for pervaporation separation of dimethyl carbonate/methanol mixtures. J. Appl. Polymer Sci. 2007, 106, 2117-2125.

11. Wang, J.; Zheng, X.; Wu, H.; Zheng, B.; Jiang, Z.; Hao, X.; Wang, B. Effect of zeolites on chitosan/zeolite hybrid membranes for direct methanol fuel cell. J. Power Source 2008, 178, 9-19.

12. Takahashi, T.; Imai, M.; Suzuki, I. Water permeability of chitosan membrane involved in deacetylation degree control. Biochem. Eng. J. 2007, 36, 43-48.

13. Casariego, A.; Souza, B.W.S.; Cerqueira, M.A.; Teixeira, J.A.; Cruz, L.; Díaz, R.; Vicente, A.A. Chitosan/clay films properties as affected by biopolymer and clay micro/nanoparticles concentrations. Food Hydrocolloid. 2009, 23, 1895-1902.

14. Guibal, E. Interactions of metal ions with chitosan-based sorbents: A review. Sep. Purif. Technol. 2004, 38, 43-74.

15. Chen, A.-H.; Liu, S.-C.; Chen, C.-Y.; Chen, C.-Y. Comparative adsorption of Cu(II), Zn(II) and $\mathrm{Pb}$ (II) ions in aqueous solution on the crosslinked chitosan with epichlorohydrin. J. Hazard. Mater. 2008, 154, 184-191.

16. Kittur, A.; Kulkarni, S.; Aralaguppi, M.; Kariduraganavar, M. Preparation and characterization of novel pervaporation membranes for the separation of water-isopropanol mixtures using chitosan and NaY zeolite. J. Membrane Sci. 2005, 247, 75-86.

17. Deng, Y.; Liu, D.; Du, G.; Li, X.; Chen, J. Preparation and characterization of hyaluronan/chitosan scaffold crosslinked by 1-ethyl-3-(3-dimethylaminopropyl) carbodiimide. Polym. Int. 2007, 56, 738-745.

18. Baroni, P.; Vieira, R.S.; Meneghetti, E.; Silva, M.G.C.; Beppu, M.M. Evaluation of batch adsorption of chromium ions on natural and crosslinked chitosan membranes. J. Hazard. Mater. 2008, 152, 1155-1163.

19. Babel, S.; Kurniawan, T.A. Cr(VI) removal from synthetic wastewater using coconut shell charcoal and commercial activated carbon modified with oxidizing agents and/or chitosan. Chemosphere 2004, 54, 951-967.

20. Santiago, I.; Worland, V.P.; Cazares-Rivera, E.; Cadena, F.C. Adsorption of Hexavalent Chromium onto Tailored Zeolites. In Proceedings of 47th Purdue Industrial Waste Conference, West Lafayette, IN, USA, 11-13 May 1992; Lewis Publishers, Inc.: Chelsea, MI, USA, 1992; Volume 1, pp. 669-710.

21. Aydın, Y.; Aksoy, N. Adsorption of chromium on chitosan: Optimization, kinetics and thermodynamics. Chem. Eng. J. 2009, 151, 188-194.

22. Guibal, E.; Van Vooren, M.; Dempsey, B.A.; Roussy, J. A review of the use of chitosan for the removal of particulate and dissolved contaminants. Sep. Sci. Technol. 2006, 41, 2487-2514. 
23. Srinivasan, A.; Viraraghavan, T. Decolorization of dye wastewaters by biosorbents: A review. J. Environ. Manage. 2010, 91, 1915-1929.

24. Redlich, O.; Peterson, D.L. A useful adsorption isotherm. J. Phys. Chem. 1959, 63, 1024-1025.

25. Clesceri, L.S.; Greenberg, A.E.; Trussell, R.R. Standard Methods for the Examination of Water and Wastewater, 17th ed.; APHA: Washington, DC, USA, 1989.

26. Jin, L.; Bai, R. Mechanisms of lead adsorption on chitosan/PVA hydrogel beads. Langmuir 2002, 18, 9765-9770.

Sample Availability: Contact the authors.

(C) 2011 by the authors; licensee MDPI, Basel, Switzerland. This article is an open access article distributed under the terms and conditions of the Creative Commons Attribution license (http://creativecommons.org/licenses/by/3.0/). 